\title{
Age and growth of the black scorpionfish, Scorpaena porcus (Pisces: Scorpaenidae) from artificial structures and natural reefs in the Adriatic Sea
}

\author{
MARIO LA MESA, GIUSEPPE SCARCELLA, FABIO GRATI and GIANNA FABI \\ CNR, Istituto di Scienze Marine, UOS di Ancona, Largo Fiera della Pesca, 60125 Ancona, Italy. \\ E-mail: m.lamesa@ismar.cnr.it
}

SUMMARY: Age and growth of the black scorpionfish, Scorpaena porcus, were estimated for different populations inhabiting natural reefs and artificial structures (artificial reefs and offshore gas platforms) in the northwestern Adriatic Sea. Annual growth increment counts were carried out on sagittal otoliths of 415 specimens ranging from 80 to $280 \mathrm{~mm}$ TL. The accuracy of age estimates was assessed by testing the annual deposition of annuli and the location of the first annulus by marginal increment analysis and daily growth increment counts, respectively. As commonly observed in other scorpaenids, annuli consisted of an alternating pattern of opaque and translucent zones. Marginal increment analysis confirmed that annuli are formed once a year, with opaque zones laid down in spring-summer and translucent zones laid down in autumn-winter. The precision of age estimates was tested by applying both the average percent error (APE) and the mean coefficient of variation (CV). The maximum age estimated for the whole sampled populations was 8 years. The von Bertalanffy growth curves were separately fitted for natural and artificial reef populations of $S$. porcus. The likelihood ratio test indicated that the overall von Bertalanffy growth curves differed significantly between the two populations. The instantaneous growth rate $\left(k\right.$, year $\left.^{-1}\right)$ and asymptotic length $\left(L_{\infty}, \mathrm{cm}\right)$ were 0.23 and 22.30 and 0.53 and 20.13 for natural and artificial reef populations, respectively. Compared with natural reef population, populations of $S$. porcus inhabiting artificial reefs and, particularly, offshore platforms, were characterized by larger and older fish. However, young-of-the-year were completely absent from the platform habitats. The effects of artificial structures on S. porcus populations in the study area are discussed in the light of previous results on scorpionfish living in other areas.

Keywords: Scorpaena porcus, age and growth, natural reefs, artificial structures, Adriatic Sea.

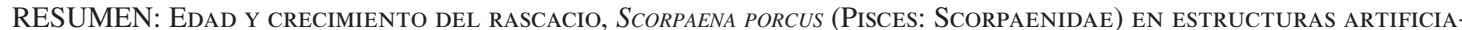
LES y ARRECIFES NATURALES EN el mar Adrí́tico. - Se estimó la edad y crecimiento del rascacio, Scorpaena porcus, de diferentes poblaciones de arrecifes naturales y estructuras artificiales (arrecifes artificiales y plataformas de gas a mar abierto) en el noroeste del mar Adriático. Los contajes de los incrementos de crecimiento anuales se realizaron en otolitos sagitta de 415 especímenes entre 80 y $280 \mathrm{~mm}$ de longitud total. La precisión de la estima de la edad se evaluó comprobando la formación anual de los anillos, y la localización del primer anillo mediante análisis de incrementos marginales y contajes de incrementos diarios, respectivamente. Tal como es comúnmente observado, los anillos presentan un patrón de zonas opacas y translúcidas que van alternando. El análisis de incrementos marginales confirmó que los anillos se forman una vez al año, con las zonas opacas que se depositan en primavera-verano y las translúcidas en otoño-invierno. La precisión en la estima de las edades se comprobó aplicando el porcentaje de error promedio y el coeficiente promedio de variación (CV). La edad máxima estimada para todas las poblaciones muestreadas fue de ocho años. Las curvas de crecimiento de von Bertalanffy growth se ajustaron separadamente para las poblaciones de $S$. porcus de arrecifes naturales y artificiales. El test de verosimilitud indicó que las curvas de crecimiento de von Bertalanffy diferían significativamente entre las dos poblaciones. La tasa instantánea de crecimiento $\left(k\right.$, año $\left.{ }^{-1}\right)$ y la longitud asintótica $\left(L_{\infty}, \mathrm{cm}\right)$ fueron 0.23 y 22.30 y 0.53 y 20.13 para poblaciones de arrecifes naturales y artificiales, respectivamente. En comparación con las poblaciones de $S$. porcus de arrecifes naturales, las que se encuentran en arrecifes artificiales y, en particular en plataformas a mar abierto, se caracterizaron por peces más grandes y de más edad. No obstante, los individuos de edad inferior a un año están completamente ausentes en dichas plataformas. El efecto de estructuras artificiales en las poblaciones de $S$. porcus en el área de estudio se discuten en función de resultados previos de scorpeniformes de otras áreas.

Palabras clave: Scorpaena porcus, edad, crecimiento, arrecifes naturales, estructuras artificiales, mar Adriático. 


\section{INTRODUCTION}

In the Mediterranean Sea, the genus Scorpaena is the most speciose group of scorpionfish, including six species, such as Scorpaena elongata Cadenat, 1943, Scorpaena loppei Cadenat, 1943, Scorpaena maderensis Valenciennes, 1833, Scorpaena notata Rafinesque, 1810, Scorpaena porcus Linnaeus, 1758, and Scorpaena scrofa Linnaeus, 1758 (Hureau and Litvinenko, 1986; Quignard and Tomasini, 2000). The genus consists of small- to medium-sized benthic fish (up to 50 $\mathrm{cm}$ TL), which are generally found on rocky, sandy or muddy bottoms from 20 to $800 \mathrm{~m}$ depth (Hureau and Litvinenko, 1986).

S. porcus, commonly known as the black scorpionfish, is one of the most common species, being distributed in the eastern Atlantic from the British Isles to Morocco and throughout the Mediterranean to the Black Sea. It is a benthic, sedentary littoral species of medium size (up to $25 \mathrm{~cm}$ ), commonly found in inshore waters among rocks and seagrass beds (Hureau and Litvinenko, 1986). It is more active and spatially dispersed in search of food by night (Pashkov et al., 1999), feeding mainly on benthic preys such as small fishes (gobies and blennies), crustaceans and other invertebrates (Bradai and Bouain, 1990; Pallaoro and Jardas, 1991; Carpentieri et al., 2001; Morte et al., 2001; Relini et al., 2002; Silvestri et al., 2002; Follesa et al., 2004). Being sedentary, S. porcus is typically a sit-and-wait ambusher, feeding almost exclusively on motile prey (Harmelin-Vivien et al., 1989).

The reproductive traits of $S$. porcus are fairly well known. Based on the annual cycle of gonadosomatic index and seasonal histology of gonads, the spawning of the black scorpionfish takes place between June and August in the western and central Mediterranean (Bradai and Bouain, 1991; Sàbat et al., 2004), the Black Sea (Koca, 2002) and the Marmara Sea (Ünsal and Oral, 1996; Çelik and Bircan, 2004). Sexual maturity is reached at two and three years of age in males and females, respectively (Bradai and Bouain, 1991; Çelik and Bircan, 2004). Unlike oviparous fishes, ovaries of $S$. porcus show several peculiar characteristics, such as pedunculate oocytes, small and scarce cortical alveoli, a thin zona radiata and a gelatinous matrix secreted during the maturation (Sàbat et al., 2004). Compared with other Mediterranean species of Scorpaena of larger size, such as S. scrofa and S. elongata (Bradai and Bouain, 1988; Ragonese et al., 2003; La Mesa et al., 2005), S. porcus is a slow-growing and short-lived fish, with a maximum life span of 11 years (SiblotBoutaflika, 1976; Bradai and Bouain, 1988; Jardas and Pallaoro, 1992). Similarly, S. porcus attains 6 and 8 years of age in the Marmara Sea (Ünsal and Oral, 1996) and Black Sea (Koca, 2002; Bilgin and Çelik, 2008; Demirhan and Can, 2009), respectively.

In the northern Adriatic Sea, S. porcus is the most common scorpionfish in coastal waters. Despite the low commercial value mainly due to their small size, $S$. porcus play an important role in hard-bottom ecosystems, being one of the main species attracted by artificial structures such as artificial reefs and offshore gas platforms and by the rare rocky habitats of the Adriatic Sea (Bombace et al., 1994; Fabi et al., 2004). In the last twenty years many artificial reefs have been built throughout the Mediterranean, in order to enhance local fish populations and to improve small scale-fisheries as a consequence of fish attraction and/or production of new biomass. Indeed, several studies report high fish density, rapid colonization and high catch rates in areas where artificial reefs have been deployed (Bohnsack and Sutherland, 1985). This is more evident in areas far from natural hard substrates, where artificial reefs can provide additional food and shelter to mitigate predation, as in the case of the Adriatic Sea (Bombace, 1982; Bombace et al., 1990, 1994; Fabi and Fiorentini, 1994).

In this study we report the age composition and growth rate of $S$. porcus estimated by otolith reading, applying indirect methods to evaluate the reliability (accuracy) and reproducibility (precision) of age estimates. A further aim was to test differences in growth parameters between populations of $S$. porcus sampled from natural and artificial reefs and to compare the growth performance of this species recorded in different areas of the Mediterranean Sea.

\section{MATERIALS AND METHODS}

Specimens of black scorpionfish (S. porcus) were collected in the northwestern Adriatic Sea between July 2004 and November 2008. The study area included both natural reefs consisting of hard substrates and artificial structures such as artificial reefs located in coastal waters and offshore gas platforms (Fig. 1). Natural and artificial reefs were located at about 0.5$3.0 \mathrm{~nm}$ from the coast, at a depth ranging from 8 to 15 $\mathrm{m}$. Offshore gas platforms were located at $18-26 \mathrm{~nm}$ from the coast on a sandy-muddy bottom, at a depth ranging from 35 to $75 \mathrm{~m}$. Roughly, each gas platform had a square base of $40 \times 40 \mathrm{~m}$, accounting for a total volume of approximately 15000 to $20000 \mathrm{~m}^{3}$. Sampling was carried out in close proximity to natural reefs and artificial structures, using a beam trawl with 40 mm cod-end mesh size and trammel nets with 70 and $400 \mathrm{~mm}$ stretched mesh size (inner and outer panel, respectively). Hauls performed with beam trawl were randomly located over the whole sampling area. The beam trawl was generally towed at about 4.8-5.2 knots for 15-30 minutes on the bottom during daylight hours. Conversely, trammel nets were set at dusk and pulled in at dawn, for a mean time of $12 \mathrm{~h}$. However, most catches (about 95\%) were obtained by trammel nets.

In the laboratory, each specimen caught was measured as total length (TL) to the nearest $\mathrm{mm}$ below and weighed as total body weight (TW) with an accuracy of $0.1 \mathrm{~g}$. Sex and stage of gonad development was assessed macroscopically following a five-point scale of maturity (Holden and Raitt, 1975). Both sagittal oto- 


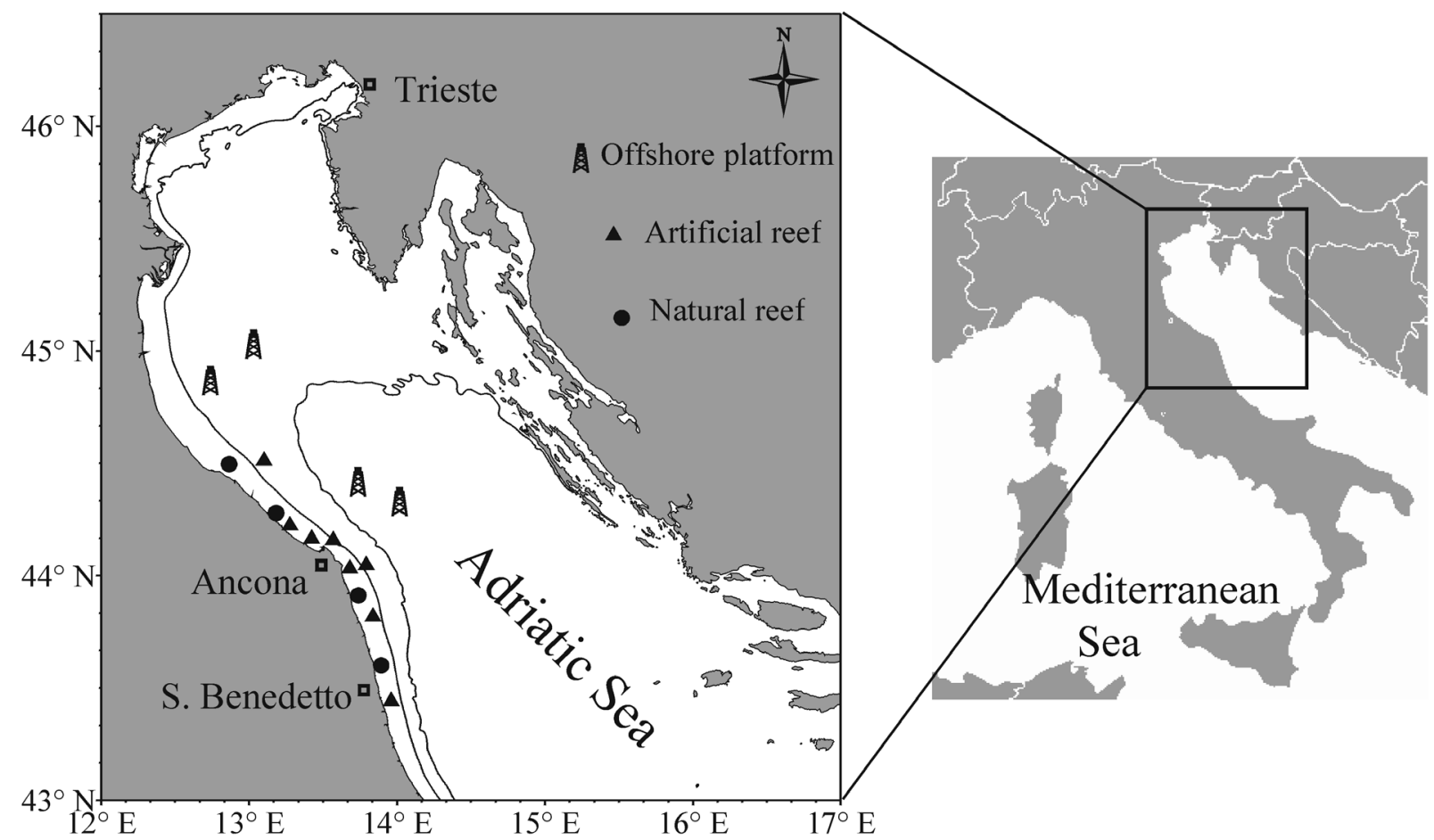

FIg. 1. - Map of northern Adriatic Sea with sampling locations of Scorpaena porcus. Solid lines indicate $20 \mathrm{~m}$ and $60 \mathrm{~m}$ depth.

liths were removed from each fish, cleaned and stored dry in numbered vials. Length-frequency distributions of $S$. porcus caught at natural and artificial reefs were compared with each other using the two-sample Kolmogorov-Smirnov test (Sokal and Rohlf, 1995).

The weight (OW), with an accuracy of $0.1 \mathrm{mg}$, and the maximum length (OL), with an accuracy of $0.1 \mathrm{~mm}$, of each otolith pair were initially recorded and compared applying a $t$ test for paired comparisons (Sokal and Rohlf, 1995). As no statistically significant difference was found between left and right otoliths (Student's $t$ test: df $=378, P>0.05$ in both cases), we arbitrarily selected right otoliths for measurements. All measurements were conducted under a stereomicroscope using an image analysis software (Image-Pro Plus, vers. 4.5.1 Media Cybernetics). The relationships between fish size (TL) and otolith size (OL) and weight (OW) were estimated by applying linear regression analysis on $\log _{10}$-transformed data, in order to correct for nonlinearity and heterogeneity of variances.

Otolith samples were fully immersed in ethanol and observed under a stereomicroscope at 25-40× magnification. Under reflected light, the nucleus and the opaque zones appeared as light rings and the translucent or hyaline zones as dark rings (Fig. 2). This pattern was quite clear also viewing the whole otolith, and therefore did not require sectioning and grinding techniques to reveal it. The combination of each opaque and subsequent translucent zone was considered to form an annulus, as observed in other scorpaenids (Massutí et al., 2000; López Abellán et al., 2001; La Mesa et al., 2005). Commonly, the annuli were formed by wide

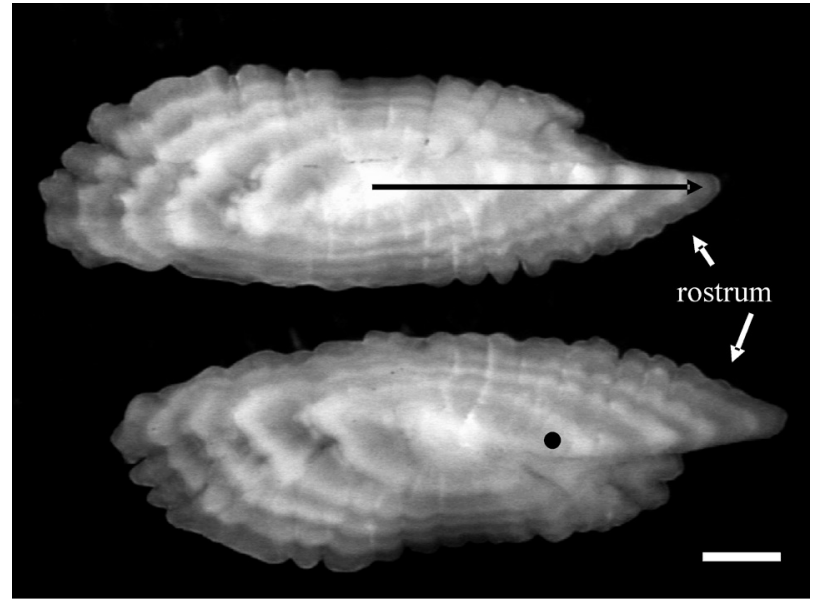

FIG. 2. - Photomicrograph of the sagittal otolith of Scorpaena porcus, showing the annulation pattern in a five-year-old female. Scale $\mathrm{bar}=1 \mathrm{~mm}$; first annulus (black dot); reading/measurement radius (black arrow).

opaque zones and narrow translucent zones. The count path showing the most unambiguous annulation pattern was generally from the nucleus towards the tip of rostrum, where the deposition of seasonal rings appeared to start. The width of each annulus was measured on this axis, with an accuracy of $0.01 \mathrm{~mm}$.

Each otolith was read by one reader, without any ancillary data on fish size. A second reading was carried out a week later by the same reader. When readings differed by one or more years, a third reading was made; if the difference still occurred, the otolith was discarded. The index of average percent error (APE) 
(Beamish and Fournier, 1981) and the mean coefficient of variation (CV) (Chang, 1982) were calculated to estimate the relative precision between readings.

To validate seasonality of deposition of opaque and translucent zones, the marginal increment analysis was carried out on the entire otolith sample (Beckman and Wilson, 1995; Panfili and Morales-Nin, 2002). Since the spawning season of $S$. porcus is between June and August (Bradai and Bouain, 1991; Sàbat et al., 2004), we considered 1 July as the birthdate of the species. We observed that the opaque nucleus was deposited during the first summer after hatching, followed by the first translucent zone laid down in the following winter just prior to the first birthday. Assuming that the annuli were laid down yearly, the age of fish was estimated by counting all the translucent zones. The final age of each fish was then estimated in months on the basis of the date of capture.

To validate specimens aged 0 , i.e. fish with sagittae composed of only an opaque nucleus, some otoliths were prepared for counting of microincrements, assuming they are laid down daily (Laidig and Ralston, 1995; Furlani, 1997; Massutí et al., 2000). Otoliths were set in moulds, embedded in epoxy resin and ground until the sagittal plane was reached. They were polished with $0.05 \mu \mathrm{m}$ alumina paste and the microincrements were counted under a light microscope at $400 \times$ and $630 \times$ magnification. The von Bertalanffy growth function was fitted to the estimated age-length data set using the FISHPARM program of the FSAS statistical package (Saila et al., 1988), applying the Marquardt algorithm for non-linear least squares parameter estimation. The von Bertalanffy growth parameters $\left(L_{\infty}, k\right.$ and $t_{0}$ ) were calculated for each population sampled in natural and artificial reefs, respectively, and compared by the likelihood ratio test (Kimura, 1980). The growth performance index $\left(\Phi^{\prime}=2 \log L_{\infty}+\log k\right.$ ) (Munro and Pauly, 1983) was then calculated to compare the different populations of $S$. porcus throughout the Mediterranean Sea.

Similarly, the length-weight relationship of fish was calculated separately for the natural reefs, artificial reefs and platform populations by fitting the exponential equation $T W=a T L^{b}$, and the allometric indices (b) were compared by applying an $F$ test (Sokal and Rohlf, 1995).

\section{RESULTS}

\section{Length-frequency distribution}

The length-frequency distributions of $S$. porcus populations caught from natural reefs (NR), artificial reefs $(A R)$ and platforms (PL) are summarized in Figure 3. Overall, 134 specimens of 110-221 mm TL were caught at the NR, 210 specimens of $80-270 \mathrm{~mm}$ TL were caught at the AR and 71 specimens of 135-280 $\mathrm{mm}$ TL were caught at the PL. All comparisons between length-frequency distributions were statistically

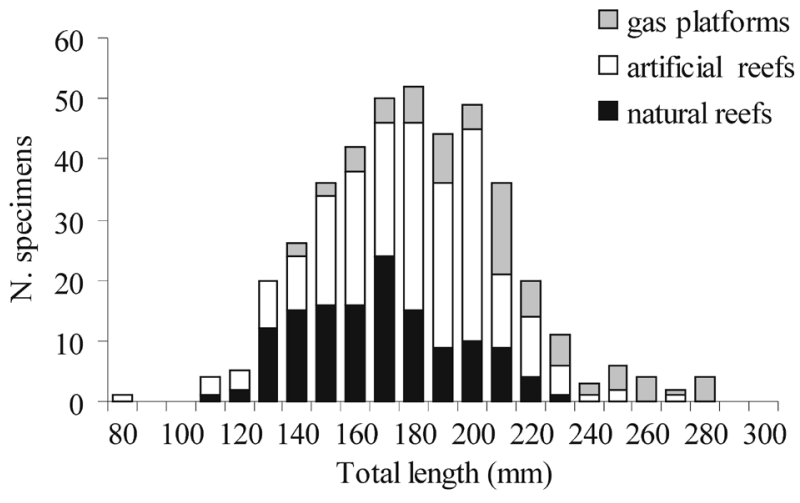

FIG. 3. - Length-frequency distribution of Scorpaena porcus from the northwestern Adriatic Sea.

different (Kolmogorov-Smirnov test, $n_{1}=134$ and $n_{2}$ $=210, P<0.01 ; n_{1}=134$ and $n_{2}=71, P<0.01 ; n_{1}=210$ and $\left.n_{2}=71, P<0.01\right)$. Indeed, the proportion of larger fish increased significantly in the AR and PL populations compared with the NR population. On the other hand, the sex ratio was not significantly different from unity in all populations (test $\chi^{2}$, df $=1, P>0.01, P>0.1$, $P>0.5$, respectively).

\section{Annulation pattern}

The inner structure of sagittal otoliths of S. porcus consisted of a wide opaque nucleus, surrounded by an alternating pattern of translucent and opaque zones of comparable width. The width of the first annulus, composed of nucleus plus the first translucent zone, was quite different among fish, whereas subsequent annuli were more regular. From the second annulus onwards, translucent and opaque zones showed a slow decrease in thickness, getting progressively narrower (Fig. 4).

Maximum otolith length (OL) and otolith weight (OW) ranged between 4.57 and $10.83 \mathrm{~mm}$ and 4.9 and $50.2 \mathrm{mg}$, respectively. The relationship between OL (mm) and TL ( $\mathrm{mm})$ was linear and negatively allometric $(b=0.77, S E=0.0019 ; t$ test, $P<0.01)$ (Fig. 5a). Instead, the relationship between OW and TL was

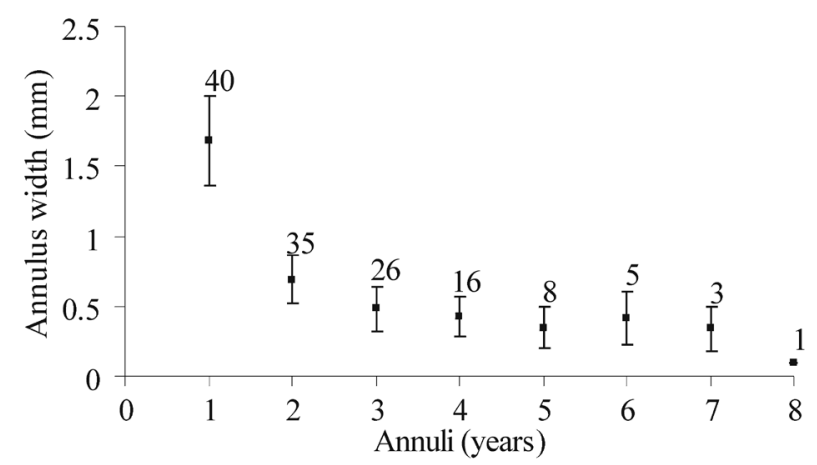

FIG. 4. - Average width of annuli observed in sagittal otoliths of Scorpaena porcus. Bars indicate standard deviations; number of specimens of each age class is indicated above bars. 

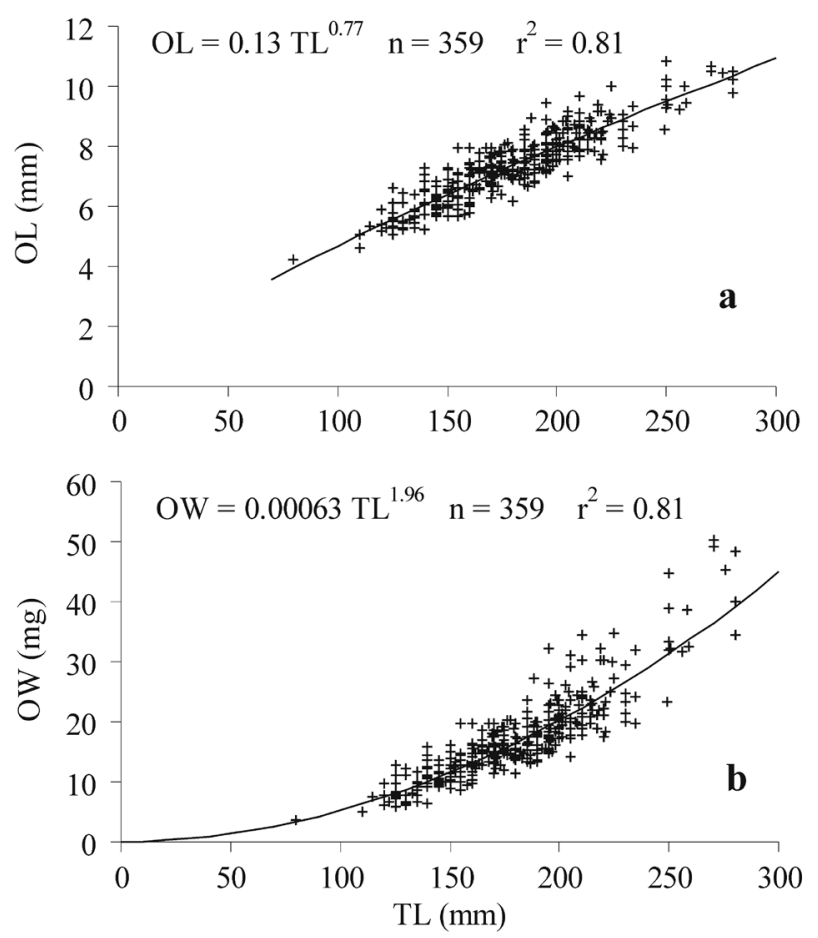

FIG. 5. - Scatter plots and fitted regression lines of maximum otolith length (OL) (a) and otolith weight (OW) (b) versus fish length (TL). curvilinear (Fig. 5b).

\section{Age estimates, accuracy and precision}

The age composition estimated for each population caught at the NR, AR and PL is summarized in the agelength keys (Table 1). Though age range and longevity

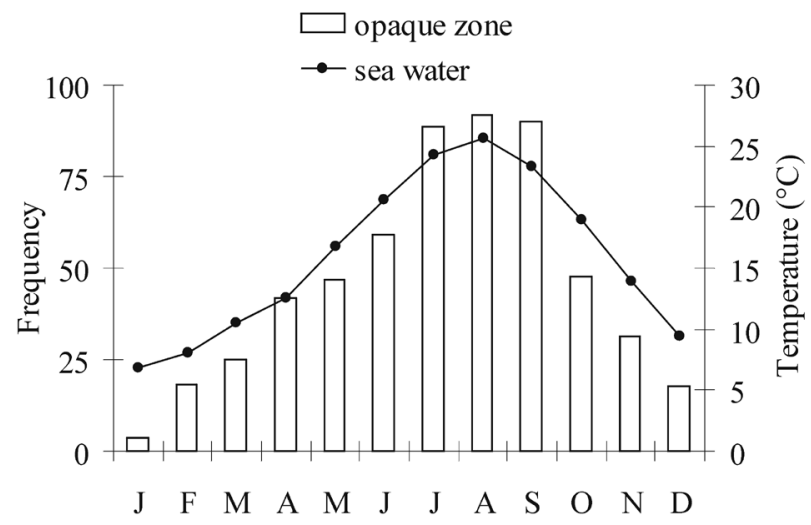

FIG. 6. - Monthly change in relative frequency of opaque zone on otolith edge of Scorpaena porcus and sea bottom temperature.

were comparable among the different populations of $S$. porcus, the proportion of older (and larger) fish increased significantly from the NR through AR and PL. In the NR, most fish (96\%) were estimated to be $0-4$ years old, with a maximum age of 7 years. In the AR, $97 \%$ of aged specimens were between 0 and 5 years, with a maximum age of 8 years. In the PL, only one specimen was younger than 2 years, whereas $94 \%$ of fish were aged between 2 and 7 years.

The annual periodicity of annulus deposition was supported by the marginal increment analysis, indicating that each pair of translucent and opaque zones was formed once a year. The opaque zone was laid down from February to August, while the translucent zone was laid down from September to January (Fig. 6). Interestingly, the seasonal trend of the opaque zone formation closely resembled the pattern of sea-bottom temperature recorded by a CTD deployed monthly on

TABLE 1. - Age-length keys of Scorpaena porcus from natural reefs and artificial structures in the Adriatic Sea.

\begin{tabular}{|c|c|c|c|c|c|c|c|c|c|c|c|c|c|c|c|c|c|c|c|c|c|c|c|c|c|c|c|}
\hline \multirow[b]{2}{*}{$T L(\mathrm{~mm})$} & \multirow[b]{2}{*}{0} & \multicolumn{8}{|c|}{ natural reefs } & \multicolumn{9}{|c|}{$\begin{array}{l}\text { Age (years) } \\
\text { artificial reefs }\end{array}$} & \multicolumn{9}{|c|}{ platforms } \\
\hline & & 1 & 2 & 3 & 4 & 5 & 6 & 7 & 8 & 0 & 1 & 2 & 3 & 4 & 5 & 6 & 7 & 8 & 0 & 1 & 2 & 3 & 4 & 5 & 6 & 7 & 8 \\
\hline 80 & & & & & & & & & & 1 & & & & & & & & & & & & & & & & & \\
\hline 90 & & & & & & & & & & & & & & & & & & & & & & & & & & & \\
\hline 100 & & & & & & & & & & & & & & & & & & & & & & & & & & & \\
\hline 110 & 1 & & & & & & & & & 2 & 1 & & & & & & & & & & & & & & & & \\
\hline 120 & & 3 & & & & & & & & 1 & 2 & & & & & & & & & & & & & & & & \\
\hline 130 & 4 & 4 & 3 & & & & & & & 2 & 3 & 4 & & & & & & & & & & & & & & & \\
\hline 140 & 1 & 4 & 6 & 3 & 1 & & & & & 1 & 2 & 2 & 3 & & & & & & & 1 & 1 & & & & & & \\
\hline 150 & 1 & 6 & 8 & 1 & & & & & & & 5 & 10 & 3 & 2 & & & & & & & 2 & 3 & & & & & \\
\hline 160 & & 1 & 7 & 6 & 2 & & & & & & 6 & 7 & 8 & 2 & & & & & & & 1 & 2 & 1 & & & & \\
\hline 170 & & & 9 & 12 & 4 & & & & & & & 4 & 13 & 9 & & & & & & & & 2 & 1 & & & & \\
\hline 180 & & & 4 & 7 & 2 & & 1 & & & & 1 & 6 & 9 & 8 & & 1 & 1 & & & & & 3 & 2 & 1 & & & \\
\hline 190 & & & 2 & 4 & 3 & & & & & & & 6 & 10 & 7 & 3 & & & 1 & & & & 3 & 3 & & & & \\
\hline 200 & & & 2 & 6 & 4 & & & & & & & 6 & 13 & 10 & 6 & 1 & & & & & & 1 & 4 & 3 & & & \\
\hline 210 & & & 2 & 2 & 2 & 2 & & 1 & & & & & 6 & 3 & 1 & & 1 & & & & 1 & 2 & 5 & 3 & & & \\
\hline 220 & & & 1 & & 1 & & & 1 & & & & & 4 & 3 & 2 & & & & & & & 1 & 2 & 2 & 3 & & \\
\hline 230 & & & & & & & & & & & & & 2 & & 1 & 1 & & & & & & & & 2 & 1 & & \\
\hline 240 & & & & & & & & & & & & & & 1 & & & & & & & & 1 & 1 & & & & \\
\hline 250 & & & & & & & & & & & & & & 1 & 1 & & & & & & & & 1 & 1 & 2 & 1 & \\
\hline 260 & & & & & & & & & & & & & & & & & & & & & & & & & & 2 & 1 \\
\hline 270 & & & & & & & & & & & & & & & 1 & & & & & & & & & & 1 & & \\
\hline 280 & & & & & & & & & & & & & & & & & & & & & & & & & & 2 & 2 \\
\hline$n$ & 7 & 18 & 44 & 41 & 19 & 2 & 1 & 2 & & 7 & 20 & 45 & 71 & 46 & 15 & 3 & 2 & 1 & & 1 & 5 & 18 & 20 & 12 & 7 & 5 & 3 \\
\hline$\%$ & 5 & 13 & 32 & 30 & 14 & 2 & 1 & 2 & & 3 & 10 & 21 & 33 & 21 & 7 & 2 & 2 & 1 & & 1 & 7 & 26 & 28 & 17 & 10 & 7 & 4 \\
\hline
\end{tabular}




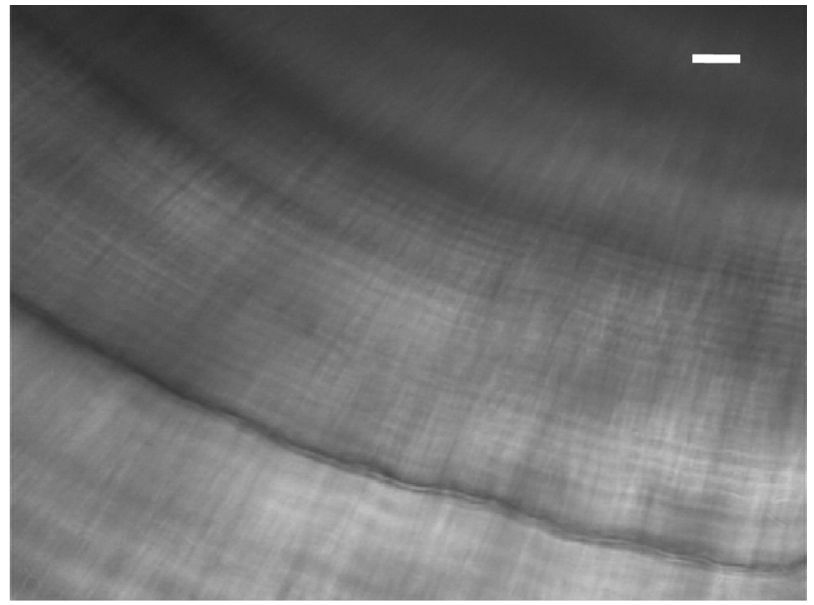

FIG. 7. - Photomicrograph of otolith microstructure in the core region, showing the typical pattern of alternating light and dark increments assumed to be deposited daily. Scale bar $=10 \mu \mathrm{m}$.

each area during the sampling period.

The microincrement counts to validate fish aged 0 (i.e. young of the year) on the basis of annuli were carried out on five specimens ranging between 80 and $135 \mathrm{~mm}$ TL. The otolith microstructure showed the typical pattern of light and dark alternated increments, representing daily growth rings (Fig. 7). A continuous series of concentric rings of increasing size ranging from 1.2 to $2.8 \mu \mathrm{m}$ was observed from the core to the otolith margin. Age estimates were from 240 to 350 days, thus validating specimens aged 0 , namely those with sagittae with an opaque nucleus and a more or less developed translucent zone.

The reliability of criteria used for ageing $S$. porcus was supported by the relatively high precision of age readings. Counting variability indices APE and CV were both quite low (9.8 and $13.9 \%$, respectively), with a percentage agreement between readings of 56\%, indicating a reasonable consistency (or reproducibility) between readings. Only $5.8 \%$ of readings differed by more than 1 year, with a maximum disagreement of 3 years.

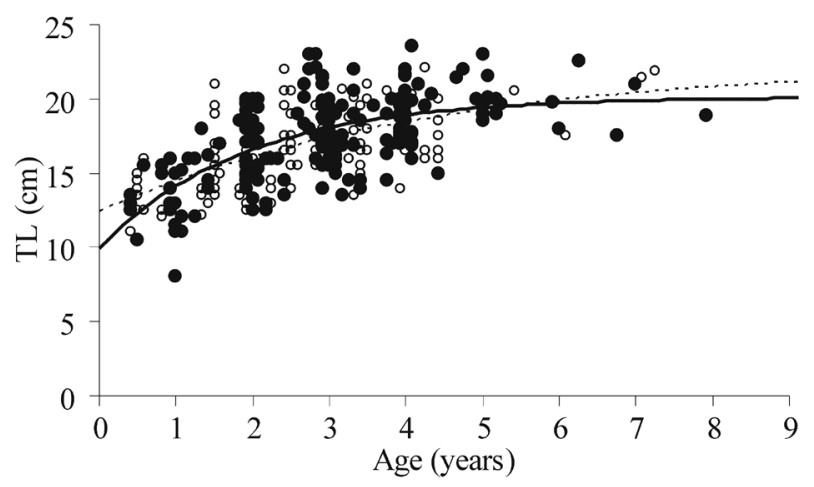

FIG. 8. - Plot of age-length data pairs and fitted von Bertalanffy growth curves for natural reef populations (open circles, dotted line) and artificial reef populations (full circles, solid line) of Scorpaena porcus from the northwestern Adriatic Sea.
TABLE 2. - Estimates of Von Bertalanffy growth parameters and growth performance of Scorpaena porcus from natural and artificial reefs in the Adriatic Sea

\begin{tabular}{lcc}
\hline Parameter & natural reefs & artificial reefs \\
\hline$L_{\infty}(\mathrm{cm})$ & $22.30(0.73)$ & $20.13(2.95)$ \\
$K\left(\mathrm{~cm}^{-1}\right)$ & $0.23(0.13)$ & $0.53(0.12)$ \\
$t_{0}($ year $)$ & $-3.43(0.48)$ & $-1.29(1.37)$ \\
$\Phi$ & 2.07 & 2.33 \\
$n$ & 134 & 207 \\
\hline
\end{tabular}

$n$, sample size; asymptotic standard errors are in brackets

TABLE 3. - Estimates of length-at-age and annual growth for Scorpaena porcus from natural reefs (NR) and artificial reefs (AR) in the Adriatic Sea

\begin{tabular}{lcccc}
\hline Age (years) & \multicolumn{2}{c}{ Length-at-age (cm) } & \multicolumn{2}{c}{ Annual growth (cm) } \\
& NR & AR & NR & AR \\
\hline 0 & 10.0 & 12.4 & & \\
1 & 14.1 & 14.4 & 4.1 & 2.2 \\
2 & 16.6 & 16.1 & 2.5 & 1.7 \\
3 & 18.1 & 17.4 & 1.5 & 1.3 \\
4 & 18.9 & 18.4 & 0.8 & 1.0 \\
5 & 19.4 & 19.2 & 0.5 & 0.8 \\
6 & 19.7 & 19.9 & 0.3 & 0.7 \\
7 & 19.9 & 20.4 & 0.2 & 0.5 \\
8 & 20.0 & 20.8 & 0.1 & 0.4 \\
\hline
\end{tabular}

\section{Growth rate}

In order to compare growth rate of populations from different areas, the von Bertalanffy growth curves were fitted to age-length data pairs estimated from natural and artificial reefs (Fig. 8), pooling data for both sexes and taking into account the same size range. Due to the small sample size, no growth curve was fitted to the population sampled off platforms. von Bertalanffy growth parameters and the derived growth performance index $\left(\Phi^{\prime}\right)$ are reported in Table 2 . The likelihood ratio test indicated that the overall von Bertalanffy growth curves differed significantly between the two populations tested $\left(\chi^{2}, \mathrm{df}=3, P<0.05\right)$, as well as combining the two parameters $L_{\infty}$ and $k\left(\chi^{2}, \mathrm{df}=2\right.$, $P<0.05)$. Instead, no statistical difference in length-atage data (Table 3 ) derived from the von Bertalanffy growth curves was observed between the two populations ( $t$ test for paired comparison, $\mathrm{df}=8, P>0.5$ ). In both populations, the annual growth rate was relatively high until they reach three years of age, i.e. at the attainment of the sexual maturity, becoming very low thereafter.

\section{Fish length-weight relationship}

The length-weight relationships of fish calculated for each of the populations caught at the NR, AR and PL are shown in Figure 9. In no relationships the slopes $(\mathrm{NR}, b=2.94, \mathrm{SE}=0.061 ; \mathrm{AR}, b=3.03, \mathrm{SE}=0.046$; $\mathrm{PL}, b=3.12, S E=0.069$ ) were significantly different from 3.00 ( $t$ test for allometry, $P>0.05$ in any case), indicating a common isometric growth. Applying an $F$ test, no difference was found between the allometric 

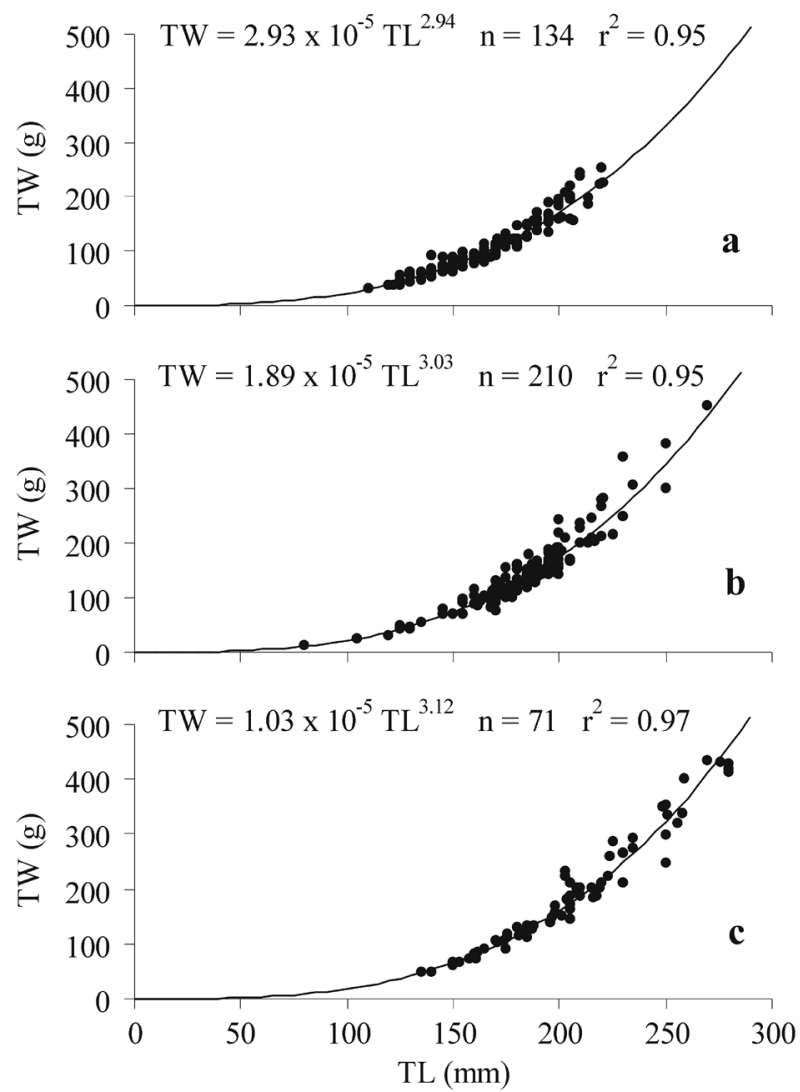

FIG. 9. - Relationships between fish length (TL) and weight (TW) for populations sampled on natural reefs (a), artificial reefs (b) and platforms (c) in the northwestern Adriatic Sea.

coefficients $(b)$ calculated for population sampled at the AR and NR $\left(F_{1,331}, P>0.1\right)$ and at the AR and PL $\left(F_{1,268}, P>0.1\right)$. Instead, the allometric coefficient was significantly different between the NR and PL populations $\left(F_{1,201}, P<0.05\right)$.

\section{DISCUSSION}

Scorpaenids are characterized by having relatively large otoliths (Tuset et al., 2008), which makes them easy to handle for ageing purposes. The inner structure of sagittal otoliths of $S$. porcus closely resembled those observed in other scorpaenids, with alternating patterns of translucent and opaque zones around an opaque nucleus. However, unlike other scorpaenid fish genera such as Helicolenus and Pontinus (Massutí et al., 2000; López Abellán et al., 2001), in S. porcus each translucent and subsequent opaque zone had the same width as each other, although their thickness slowly decreased towards the otolith margin. A similar pattern was also observed in sagittal otoliths of Scorpaena maderensis (La Mesa et al., 2005).

Consistent with many other scorpaenids, such as $H$. dactylopterus (Massutí et al., 2000), Scorpaena guttata (Love et al., 1987), S. maderensis (La Mesa et al., 2005) and Sebastes spp. (Love et al., 1990), the present results showed that annuli in sagittal otoliths of $S$. porcus are laid down annually, the opaque zone being generally deposited in spring-summer and the translucent zone in autumn-winter (Morales-Nin, 2001). Moreover, the great consistency among repeated age readings makes otoliths the most reliable hard part for ageing scorpaenid fish.

Several studies concerning age and growth of $S$. porcus are currently available across their geographical distribution (Table 4). The estimated life span of this species is generally 6-7 years of age and is very similar among populations from different areas, except for the population inhabiting the northeastern sector of the Adriatic Sea (Table 4). Interestingly, a striking difference in life span seems to occur between northeastern and northwestern Adriatic populations of $S$. porcus (Jardas and Pallaoro, 1992; present data), possibly related to different environmental conditions and/ or different fishing pressure. As far as growth parameters are concerned, there is a good agreement between the maximum attainable sizes (i.e. asymptotic length, $\left.L_{\infty}\right)$ and instantaneous growth rates $(k)$ estimated from different populations, as well as the derived growth performance index ( $\left.\Phi^{\prime}\right)$ (Table 4). On the other hand, the Black Sea population of $S$. porcus seems to be able to attain a larger maximum size at a lower growth rate (Koca, 2002). In two most recent studies from the Black Sea, the von Bertalanffy growth function did not adequately model the growth of $S$. porcus, providing an unreliable estimate of asymptotic length (Bilgin and Çelik, 2008; Demirhan and Can, 2009).

Despite the wide increasing distribution of artificial reefs over the past century, intentionally deployed on the seafloor to increase the abundance of commercially and recreationally important fish species (Brickhill et al., 2005), little is known about the comparative ecological performance of fishes associated with artificial habitats compared to those inhabiting natural habitats (Carr and Hixon, 1997). A pilot study showed that young-of-the-year blue rockfish (genus Sebastes) grew faster at an offshore oil platform than at a natural out-

TABLE4.-Estimates of VonBertalanffy growth parametersandagerange forScorpaenaporcus fromdifferentareas. $\Phi$ '= growth performanceindex

\begin{tabular}{lcccll}
\hline$L_{\infty}(\mathrm{cm})$ & $K\left(\right.$ year $\left.^{-1}\right)$ & $t_{0}($ year $)$ & $\Phi$ & Age (years) & Area \\
\hline 32.4 & 0.18 & -0.93 & 2.28 & - & Ligurian Sea \\
28.2 & 0.18 & -0.80 & 2.16 & $1-11$ & Adriatic Sea Silvestri et al. (2002) \\
23.1 & 0.16 & -0.85 & 1.93 & $1-6$ & Gulf of Gabes \\
29.3 & 0.16 & 0.97 & 2.14 & $1-7$ & Algerian Sea \\
24.4 & 0.16 & -1.19 & 1.98 & $1-7$ & Marmara Sea \\
40.8 & 0.11 & -2.23 & 2.26 & $1-6$ & Black Sea \\
\hline
\end{tabular}


crop, indicating that juvenile fishes at platforms are at least as healthy as those around natural outcrops (Love et al., 2007). Without entering into the ongoing attraction versus production debate to explain the increased fish abundance on artificial reefs (Brickhill et al., 2005), the effects of artificial structures on the black scorpionfish were particularly evident in the northwestern Adriatic Sea, where they were far from natural hard substrates and totally encircled by sandy or muddy bottoms. There, soon after artificial reef deployment, fish abundance, species richness and diversity gradually increased, especially as a consequence of the increase in hard-substrate species (such as sciaenids and scorpaenids), which were rare or absent in the original natural soft bottom habitat (Bombace et al., 1994).

Other than an increased fish abundance as a positive outcome, artificial structures located in the study area seem to benefit $S$. porcus populations in terms of maximum size, growth performance and longevity. This was true mainly for the population inhabiting areas around offshore gas platforms. The platform bases appear to be important to several fish species (Love et al., 2007), as they provide both refuge and prey especially for those species with cryptobenthic habits, like rockfishes or scorpionfishes. These fish often exhibit variegated colour patterns that blend well with their surroundings, thus enabling them to remain undetected by their prey. In addition, platforms usually harboured higher densities of young-of-the-year rockfishes than natural outcrops and thus may be functionally more important as nurseries (Love et al., 2003).

Instead, the population of $S$. porcus sampled around offshore platforms in the northwestern Adriatic Sea consisted almost exclusively of large fish older than two years. Two opposing but not mutually exclusive hypotheses might be proposed to explain this finding. Young-of-the-year of black scorpionfish inhabit preferentially platform midwaters, as reported in rockfishes off California (Love et al., 2003), avoiding being caught by trammel net set on the sea bottom or beam trawling. Alternatively, young-of-theyear are actually absent around offshore platforms because spawning (and nursery) areas of the species are located in coastal waters. Indeed, early life stages of scorpaenids are generally more concentrated in coastal than offshore waters in the western Mediterranean (Crec'hriou et al., 2008). In addition, the black scorpionfish larvae are pelagic for a relatively short time (i.e. just a month) before settlement (Raventós and Macpherson, 2001), and therefore find it difficult or impossible to reach offshore platforms and settle in their proximity. As a consequence, the population of $S$. porcus living around offshore platforms might be sustained by individuals settled inshore. Though more scorpaenids are rather sedentary, movement of more than $200 \mathrm{~km}$ has been demonstrated for the California scorpionfish, Scorpaena guttata, which seems to be able to move freely through midwater and travel long distances, presumably to spawn (Hartmann, 1987).

\section{REFERENCES}

Beamish, R.J. and D.A. Fournier. - 1981. A method of comparing the precision of a set of age determinations. Can. J. Fish. Aquat. Sci., 38: 982-983.

Beckman, D.W. and C.A. Wilson. - 1995. Seasonal timing of opaque zone formation in fish otoliths. In: D.H. Secor, J.M. Dean and S.E. Campana (eds.), pp. 27-43. Recent Developments in Fish otolith Research, University of South Carolina Press, Columbia.

Bilgin, S. and Ş. Çelik. - 2008. Age, growth and reproduction of the black scorpionfish, Scorpaena porcus (Pisces, Scorpaenidae), on the Black Sea coast of Turkey. J. Appl. Ichthyol., 25: 1-6.

Bohnsack, J.A. and D.L. Sutherland. - 1985. Artificial reef research: a review with recommendations for future priorities. Bull. Mar. Sci., 37: 11-39.

Bombace, G. - 1982. II punto sulle barriere artificiali: problemi e prospettive. Natur. sicil. IV Suppl. 3: 573-591.

Bombace, G., G. Fabi and L. Fiorentini. - 1990. Preliminary analysis of catch data from artificial reefs in Central Adriatic. FAO Fish. Rep., 428: 86-98.

Bombace, G., G. Fabi, L. Fiorentini and S. Speranza. - 1994. Analysis of the efficacy of artificial reefs located in five different areas of the Adriatic Sea. Bull. Mar. Sci., 55: 528-538.

Bradai, N. and A. Bouain. - 1988. Age et croissance de Scorpaena porcus et Scorpaena scrofa du golfe de Gabes. Bull. Inst. Natn. Scient. Tech. Océanogr. Pêche Salammbô, 15: 13-38.

Bradai, N. and A. Bouain. - 1990. Feeding pattern of Scorpaena porcus and S. scrofa (Teleostei, Scorpaenidae) from Gulf of Gabes, Tunisia. Cybium, 14: 207-216.

Bradai, N. and A. Bouain. - 1991. Reproduction de Scorpaena porcus (Linnaeus, 1758) et de Scorpaena scrofa (Linnaeus, 1758) (Pisces, Scorpaenidae) du Golfe de Gabes. Oebalia, 17: 167-180.

Brickhill, M.J., S.Y. Lee and R.M. Connolly. - 2005. Fishes associated with artificial reefs: attributing changes to attraction or production using novel approaches. J. Fish Biol., 67: 53-71.

Carpentieri, P., F. Colloca, A. Belluscio and A. Ardizzone. - 2001. Preliminary notes on feeding habits of Scorpaena porcus (Linnaeus, 1758) in the central Tyrrhenian Sea. Biol. Mar. Medit., 8: 699-703.

Carr, M.H. and M.A. Hixon. - 1997. Artificial reefs: the importance of comparisons with natural reefs. Fisheries, 22: 28-33.

Çelik, E.Ş. and R. Bircan. - 2004. An investigation on the reproduction characteristics of the Black scorpionfish (Scorpaena porcus Linnaeus, 1758) in Dardanelles. Sci. Engin. J. Firat Univ., 16: 327-335.

Chang, W.Y.B. - 1982. A statistical method for evaluating the reproducibility of age determination. Can. J. Fish. Aquat. Sci., 39: 1208-1210.

Crec'hriou, R., P. Bonhomme, G. Criquet, G., Cadiou, P. Lenfant, G. Bernard, E. Roussel, L. Le Diréach and S. Planes. - 2008. Spatial patterns and GIS habitat modelling of fish in two French Mediterranean coastal areas. Hydrobiol., 612: 135-153.

Demirhan, S.A. and M.F. Can. - 2009. Age, growth and food composition of Scorpaena porcus (Linnaeus, 1758) in the southeastern Black Sea. J. Appl. Ichthyol., 25: 215-218.

Fabi, G. and L. Fiorentini. - 1994. Comparison between an artificial reef and a control site in the Adriatic Sea: analysis of four years of monitoring. Bull. Mar. Sci., 53: 538-558.

Fabi, G., F. Grati, M. Puletti and G. Scarcella. - 2004. Effects on fish community induced by installation of two gas platforms in the Adriatic Sea. Mar. Ecol. Progr. Ser., 273: 187-197.

Follesa, M.C., S. Cabiddu, A. Sabatini and A. Cau. - 2004. Relazioni trofiche nelle specie di Scorpaena (Linneo, 1758) del Mediterraneo centro-occidentale. Biol. Mar. Medit., 11: 586-591.

Furlani, D.M. - 1997. Development and ecology of ocean perch larvae, Helicolenus percoides (Richardson, 1842), (Pisces: Scorpaenidae) from southern Australian waters, with notes on the larvae of other sympatric scorpaenid genera. Mar. Freshw. Res., 48: 311-320.

Harmelin-Vivien, M.L., R.A. Kaim-Malka, M. Ledoyer and S.S. Jacob-Abraham. - 1989. Food partitioning among scorpaenid fishes in Mediterranean seagrass beds. J. Fish Biol., 34 : 715-734.

Hartmann, A.R. - 1987. Movement of scorpionfishes (Scorpaeni- 
dae: Sebastes and Scorpaena) in the Southern California Bight. California Fish. Game, 73: 68-79.

Holden, M.J. and D.F.S. Raitt. - 1975. Manual of fisheries science. Part 2. Methods of resource investigations and their application. FAO Fish. Tech. Pap., 115: 1-214.

Hureau, J.C. and N.I. Litvinenko. - 1986. Scorpaenidae. In: W. Fischer, M.L. Bauchot, and M. Schneider (eds.), pp. 1211-1229. Fiches FAO d'identification des espèces pour les besoins de la pêche (Révision 1). Méditerranée et mer Noire. Zone de pêche 37, vol. 2, FAO, Rome.

Jardas, I. and A. Pallaoro. - 1992. Age and growth of black scorpionfish, Scorpaena porcus L., 1758 in the Adriatic Sea. Rapp. Comm. Int. Mer Médit., 33: 296.

Kimura, D.K. - 1980. Likelihood methods for the von Bertalanffy growth curve. Fish. Bull., 77: 765-776.

Koca, H.U. - 2002. A study on the determination of some parameters of the scorpion fish (Scorpaena porcus Linneus, 1758) caught by bottom nets in the area of Sinop in terms of fishery biology. Turk. J. Veter. Anim. Sci., 26: 65-69.

La Mesa, M., G. La Mesa and M. Micalizzi. - 2005. Age and growth of madeira scorpionfish, Scorpaena maderensis Valenciennes, 1833, in the central Mediterranean. Fish. Res., 74: 265-272.

Laidig, T.E. and S. Ralston. - 1995. The potential use of otolith characters in identifying larval rockfish (Sebastes spp.). Fish. Bull., 93: 166-171

López Abellán, L.J., M.T.G. Santamaría and P. Conesa. - 2001. Age and growth of Pontinus kuhlii (Bowdich 1825) in the Canary Islands. Sci. Mar., 65: 259-267.

Love, M.S., B. Axell, P. Morris, R. Collins and A. Brooks. - 1987. Life history and fishery of the California scorpionfish, Scorpaena guttata, within the Southern California Bight. Fish. Bull., 85: 99-116.

Love, M.S., P. Morris, M. McCrae and R. Collins. - 1990. Life history aspects of 19 rockfish species (Scorpaenidae: Sebastes) from the Southern California Bight. NOAA Tech. Rep., 87: 1-38.

Love, M.S., D.M. Schroeder and M.M. Nishimoto. - 2003. The ecological role of oil and gas production platforms and natural outcrops on fishes in southern and central California: a synthesis of information. US Dept Int, US Geological Survey, Biological Resources Division, Seattle, 98104, OCS Study MMS 2003-032.

Love, M.S., E. Brothers, D.M. Schroeder and W.H. Lenarz. - 2007. Ecological performance of young-of-the-year blue rockfish ( $\mathrm{Se}$ bastes mystinus) associated with oil platforms and natural reefs in California as measured by daily growth rates. Bull. Mar. Sci., 80: $147-157$

Massutí, E., B. Morales-Nin and J. Moranta. - 2000. Growth variability of blue-mouth Helicolenus dactylopterus (Osteichthyes: Scorpaenidae) in two western Mediterranean areas: Alboran Sea and Balearic Sea. Fish. Res., 46: 165-176.

Morales-Nin, B. - 2001. Mediterranean deep-water fish age determination and age validation: the state of the art. Fish. Res., 51 377-383.
Morte, S., M.J. Redon and A. Sanz-Brau. - 2001. Diet of Scorpaena porcus and Scorpaena notata (Pisces: Scorpaenidae) in the western Mediterranean. Cah. Biol. Mar., 42: 333-344.

Munro, J.L. and D. Pauly. - 1983. A simple method for comparing growth of fishes and invertebrates. ICLARM Fishbyte, 1: 5-6.

Pallaoro, A. and I. Jardas. - 1991. Food and feeding habits of black scorpionfish (Scorpaena porcus L. 1758) (Pisces, Scorpaenidae) along the Adriatic coast. Acta Adriat., 32: 885-898.

Panfili, J. and B. Morales-Nin. - 2002. Validation and verification methods. B. Semi-direct validation. In: J. Panfili, H. de Pontual, H. Troadec and P.J. Wright (eds)., pp. 129-134. Manual of Fish Sclerochronology, IFREMER, France.

Pashkov, A.N., N.F. Shevchenko, L.S. Oven, V.E. Giragosov and M.V. Kruglov. - 1999. Distribution, numbers, and principal population index of Scorpaena porcus under anthropogenic pollution of the Black Sea. J. Ichthyol., 39: 634-641.

Quignard, J.-P. and J.A. Tomasini. - 2000. Mediterranean fish biodiversity. Biol. Mar. Medit., 7: 1-66.

Relini, G., M. Relini, G. Torchia and G. De Angelis. - 2002. Trophic relationships between fishes and an artificial reef. ICES J. Mar. Sci., 59: S36-S42.

Ragonese, S., S. Gancitano, G. Norito, P. Rizzo and G. Bono. 2003. Life history traits of the slender rockfish, Scorpaena elongata Cadenat, 1943 (Pisces - Scorpaenidae), of the Strait of Sicily (Mediterranean Sea). Biol. Mar. Medit., 10: 223-232.

Raventós, N. and E. Macpherson. - 2001. Planktonic larval duration and settlement marks on the otoliths of Mediterranean littoral fishes. Mar. Biol., 138: 1115-1120.

Sàbat, M., M.R. Hernandez, M. Muñoz and M. Casadevall. - 2004. Ovarian structure and annual reproductive cycle of Scorpaena porcus. Rapp. Comm. Int. Mer Médit., 37: 431.

Saila, S., C. Recksiek and M. Prager. - 1988. Basic Fishery Science Programs. Amsterdam, Elsevier.

Siblot-Boutéflika, D. - 1976. Contribution à létude des Scorpaenidae de la région Alger. Thèse Doc 3ème Cycle Océanographie, Univ. Aix-Marseille II, $181 \mathrm{pp}$.

Silvestri, R., A. Voliani and A. Zucchi. - 2002. Nota sulla biologia di Scorpaena porcus Linneo, 1758 nel Mar Ligure meridionale. Biol. Mar. Medit., 9: 813-817.

Sokal, R.R. and F.J. Rohlf. - 1995. Biometry. The principle and practice of statistics in biological research. WH Freeman and Co, San Francisco.

Tuset, V.M., A. Lombarte and C.A. Assis. - 2008. Otolith atlas for the western Mediterranean, north and central eastern Atlantic. Sci. Mar., 72S1: 7-198.

Ünsal, N. and M. Oral. - 1996. A study on the growth and reproduction of black scorpionfish (Scorpaena porcus Linnaeus, 1758) in the Sea of Marmara. Turk. J. Zool., 20: 303-308.

Scient. ed.: B. Morales-Nin.

Received September 1, 2009. Accepted January 28, 2010.

Published online July 6, 2010. 